\title{
$\mathrm{A}_{2} \mathrm{~B}$ 표현형을 가진 캄보디아인에서 발견된 이중 특이성을 갖는 당전이효소를 부호화하는 희귀한 $A B O$ 대립 유전자
}

유홍비 ${ }^{1} \cdot$ 정유나 $^{2} \cdot$ 김태열 $^{2} \cdot$ 서은상 ${ }^{2} \cdot$ 최광모 $^{2} \cdot$ 조 덕 $^{1,2}$

성균관대학교 삼성융합의과학원 융합의과학과', 성균관대학교 의과대학 삼성서울병원 진단검사의학과 ${ }^{2}$

\section{Rare ABO Allele Encoding Glycosyltransferase with Dual Specificity Found in a Cambodian Individual with the $\mathrm{A}_{2} \mathrm{~B}$ Phenotype}

\author{
HongBi Yu, B.S. ${ }^{1}$, Yoo Na Chung, M.D. ${ }^{2}$, Tae Yeul Kim, M.D. ${ }^{2}$, Eunsang Suh, M.D. ${ }^{2}$, \\ Kwang Mo Choi, M.T. ${ }^{2}$, Duck Cho, M.D. ${ }^{1,2}$ \\ Department of Health Sciences and Technology, SAIHST, Sungkyunkwan University', Seoul; Department of Laboratory Medicine and \\ Genetics, Samsung Medical Center, Sungkyunkwan University School of Medicine², Seoul, Korea
}

Cis- $A B$ and $B(A)$ alleles encode an $\mathrm{ABO}$ enzyme with dual A and B glycosyltransferase activity. Although globally rare, the cis-AB phenotype is found relatively often in Korean, Japanese, and Chinese populations. Cases of the $B(A)$ allele have been reported mostly in the Chinese population. Forward typing performed in a Cambodian woman with an $\mathrm{ABO}$ discrepancy demonstrated a strong reaction with anti- $\mathrm{A}$ and anti-B reagents, while there was no reaction with lectin anti- $A_{1}$. The anti- $A_{1}$ antibody was detected in reverse typing. Through $A B O$ gene sequence analyses of exons 6 and 7, one of the alleles was identified as $A B O * B .01$. In contrast, the other allele harboring a c.803G $>C$ substitution was either $A B O * c i s A B .05$ or $A B O * B A .06$ allele. The $A B O * c i s A B .05$ and $A B O * B A .06$ alleles remain indistinguishable despite routine serological testing and $A B O$ genotyping. To the best of the author's knowledge, this is the first case report of these variants discovered in a Cambodian individual residing in Korea. (Korean J Blood Transfus 2020;31:254-259)

Key words: ABO, Genotyping, cis- $A B, B(A)$

\section{Introduction}

The $A B O$ gene encodes a glycosyltransferase, which catalyzes the transfer of carbohydrates to the $\mathrm{H}$ antigen, thereby converting the $\mathrm{H}$ antigen into $\mathrm{A}$ or $\mathrm{B}$ antigens, depending on the encoding allele. The common $\mathrm{ABO}$ phenotypes in Korea are mostly encoded

Received on June 19, 2020. Revised on July 31, 2020. Accepted on August 10, 2020

Correspondence to: Duck Cho, M.D.

Department of Laboratory Medicine and Genetics, Samsung Medical Center, Sungkyunkwan University School of Medicine, 81 Irwon-ro, Gangnam-gu, Seoul 06351, Korea

Tel: 82-2-3410-2403, Fax: 82-2-3410-2719, E-mail: duck.cho@skku.edu, ORCID: https://orcid.org/0000-0001-6861-3282

@) This is an Open Access article distributed under the terms of the Creative Commons Attribution Non-Commercial License (http://creativecommons.org/licenses/by-nc/4.0) which permits unrestricted non-commercial use, distribution, and reproduction in any medium, provided the original work is properly cited.

Copyright (C) 2020 The Korean Society of Blood Transfusion 
by $A B O * A 1.02, A B O^{*} B .01, A B O^{*} 0.01 .01$, and $A B O^{*}$ O.01.02 alleles, whereas weak ABO phenotypes are encoded by other ABO subgroup alleles, such as $A B O * \operatorname{cis} A B .01, A B O * A 2.01, A B O * A 2.04, A B O * B 3.03$, $A B O * B 3.06$, and $A w 10$ [1-3]. Among ABO subgroup alleles, the $B(A)$ and $c i s-A B$ alleles can encode an enzyme with both $A$ and $B$ glycosyltransferase activities [4]. This dual enzymatic activity of cis-AB results in a typical phenotype of $\mathrm{A}_{2} \mathrm{~B}_{3}$ expressing decreased levels of $\mathrm{A}$ and $\mathrm{B}$ antigens; $\mathrm{B}(\mathrm{A})$, on the other hand, is distinguished by very low A antigen levels and normal $B$ antigen levels.

The cis-AB is relatively common in the Korean, Japanese, and Chinese populations. To date, several cis- $A B$ alleles such as $A B O{ }^{*} \operatorname{cis} A B .01, A B O{ }^{*} \operatorname{cis} A B .04$, and $A B O^{*}$ cis $A B .09$ have been reported in Koreans $[1,5,6]$. However, $A B O *$ cis $A B .05$ alleles remain unexplored outside the Chinese population. In contrast to $c i s-A B$ alleles, $B(A)$ alleles have not been identified by molecular genetic testing in Koreans and Japanese despite their abundance in Chinese. Finally, no cases of $c i s-A B$ and $B(A)$ alleles have been yet reported in Cambodians.
Here, we report for the first time, a case of a Cambodian individual suspected of having an $A B O *$ cisAB.05 or $A B O * B A .06$ allele.

\section{Case Report}

A peripheral blood sample from a 25 -year-old Cambodian woman with an ABO discrepancy was sent to Samsung Medical Center. The proband was identified to have an $\mathrm{A}_{2} \mathrm{~B}$ phenotype by serological method. $\mathrm{RBCs}$ of the proband showed strong agglutination reactions with anti-A and anti-B reagents (Ortho Clinical Diagnostics, Raritan, NJ, USA), but no reaction with anti-A $A_{1}$ lectin (Ortho Clinical Diagnostics). Anti$\mathrm{A}_{1}$ antibody was detected in the plasma (Table 1). Sequence analysis of exons 6 and 7 of the $A B O$ gene was performed according to the previously described method [1], and revealed a heterozygous sequence ( $\mathrm{C}$ and $\mathrm{G})$ at nucleotide 803 . Allele specific polymerase chain reaction (AS-PCR) for allele separation was subsequently carried out for two sequences. AS-PCR with sequence covering the c.261 to c.803 was performed as previously described [7] and of sequence covering the

Table 1. Comparison of the serological results of $c i s-A B 05, B(A) 06$, and proband

\begin{tabular}{|c|c|c|c|c|c|c|c|c|c|c|}
\hline & \multicolumn{7}{|c|}{ Forward typing } & \multicolumn{2}{|c|}{ Reverse typing } & \multirow{3}{*}{ Ref } \\
\hline & \multirow{2}{*}{\multicolumn{2}{|c|}{$\frac{\text { Anti-A }}{\text { monoclonal polyclonal }}$}} & \multirow{2}{*}{ Anti- $A_{1}$} & \multicolumn{2}{|c|}{ Anti-B } & \multirow{2}{*}{ Anti-A,B } & \multirow{2}{*}{ Anti-H } & \multirow{2}{*}{$A_{1}$ cell } & \multirow{2}{*}{ B cell } & \\
\hline & & & & monoclo & olyclonal & & & & & \\
\hline $\begin{array}{l}A B O * B A .06 / \\
* 0.01 .01\end{array}$ & $4+$ & - & - & $4+$ & $4+$ & $4+$ & $4+$ & $2+$ & - & {$[4]$} \\
\hline $\begin{array}{c}A B O * \operatorname{cis} A B .05 \\
/ * 0.01 .01\end{array}$ & $4+$ & $4+$ & - & $4+$ & $4+$ & $4+$ & $4+$ & - & - & {$[14]$} \\
\hline $\begin{array}{c}A B O * \operatorname{cis} A B .05 \text { or } \\
{ }_{B} B A .06 / * B .01\end{array}$ & $4+$ & NT & - & $4+$ & NT & NT & NT & $3+$ & - & $\begin{array}{l}\text { In this } \\
\text { case }\end{array}$ \\
\hline
\end{tabular}


c.803 to c.1096 was performed using primer pairs 803G-F (GGCGATTTCTACTACCTGGGCGG) and ABO + 19915AS (GGCGTATCTGCGATTGCGTGT) [8]. The proband harbored a rare c. $803 \mathrm{C}>\mathrm{G}$ substitution ( $\mathrm{p}$. Ala268Gly) in the $A B O * B .01$ allele (Fig. 1). This variant is annotated as $A B O * \operatorname{cis} A B .05$ and $A B O * B A .06$ in the International Society of Blood Transfusion (ISBT) database [9].

\section{Discussion}

To date, several weak ABO subgroups have been discovered in various populations. Although $\mathrm{ABO}$ subgroups are rare, they are a leading cause of $\mathrm{ABO}$ discrepancy [10]. In most cases, weak phenotypes result from the expression of a variant $\mathrm{ABO}$ allele, which can be revealed by molecular genetic analysis, thereby resolving the ABO discrepancy. Cho et al. reported their results with the resolution of $\mathrm{ABO}$ discrepancies by $A B O$ genotyping [11]. In this study, serological analysis revealed ABO discrepancy with $A_{2} B$ phenotype and the presence of anti- $A$ in patient's serum. It was speculated that the underlying genotype of the $\mathrm{A}_{2} \mathrm{~B}$ phenotype could be $\operatorname{cis}-A B / B$,

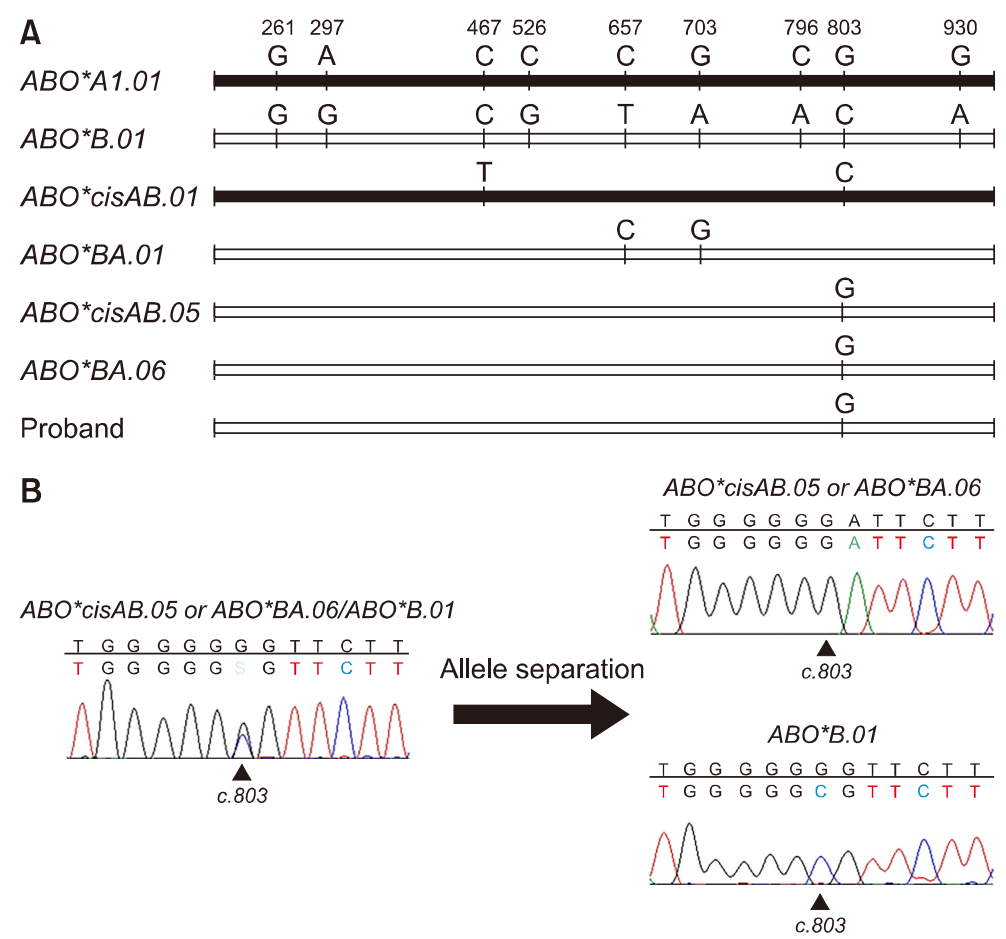

Fig. 1. (A) Genetic characterization of $c i s-A B$ and $B(A)$ alleles (in exons 6 and 7 of the $A B O$ gene). The black and white boxes indicate the A and B backbones, respectively. (B) Sequencing chromatograms of a proband with nucleotide substitutions at position 803 . The left chromatogram reveals a heterozygous sequence $(\mathrm{C}$ and $\mathrm{G})$ at c.803. The two right chromatograms reveal the $A B O{ }^{*} \operatorname{cis} A B .05$ or $A B O * B A .06$ allele and $A B O * B .01$ allele. 
Table 2. Estimated $c i s-A B$ and $B(A)$ frequency in the Asian population

\begin{tabular}{lcccc}
\hline \multirow{2}{*}{ Allele } & \multicolumn{3}{c}{ Frequency $\left({ }^{*} 10-5\right)$} & \multirow{2}{*}{ Ref } \\
\cline { 2 - 4 } & China & Japan & Korea & \\
\hline$B(A) 02$ & 0.78 & N/A & N/A & {$[13]$} \\
$B(A) 04$ & 1.6 & N/A & N/A & {$[13]$} \\
$B(A) 06$ & 0.3 & N/A & N/A & {$[13]$} \\
cisAB01 & 0.66 & 1.2 & 35.4 & {$[12]$} \\
cisAB05 & N/A & N/A & N/A & \\
\hline
\end{tabular}

Abbreviation: N/A, not applicable.

$B(A) / B, B(A) / O$, or $A_{2} / B[12,13]$. Interestingly, the $A B O$ genotyping demonstrated that the proband harbored the c.803C $>\mathrm{G}$ variant (p.Ala268Gly) in the wild type $B$ allele $\left(A B O^{*} B .01\right)$, which corresponded to $A B O *$ cis $A B .05$ or $A B O * B A .06$ allele. In this study, we tried to distinguish whether this allele is $A B O^{*}$ cis $A B .05$ or $A B O^{*} B A .06$. However, the distinction between the two alleles is inherently infeasible, as the nucleotide sequences of the two alleles registered in the ISBT database (only covering exons 6 and 7) are identical. The regions outside of exons 6 and 7 have not been previously reported and further studies are needed to determine the nucleotide sequences in $\mathrm{ABO}$ exons $1 \sim 5$ and the flanking regions of the two alleles. In fact, the distinction between the two alleles has no clinical implication.

The $A B O^{*}$ cis $A B .05$ and $A B O * B A .06$ alleles have been reported only in one Chinese subject with an $\mathrm{A}_{2} \mathrm{~B}$ phenotype $[4,14]$. However, $\mathrm{B}(\mathrm{A})$ blood group types and $A B O^{*}$ cis $A B .05$ allele have never been confirmed by molecular analysis, although other alleles of $c i s-A B$ blood group, such as $A B O{ }^{*}$ cis $A B .01$ and $A B O *$ cis $A B .04$, have been reported in Korean and Japanese populations [12]. In Chinese popula- tion, $\mathrm{B}(\mathrm{A})$ is more abundant than cis-AB blood group [13]. Among $B(A)$ alleles, $A B O * B A .04$ is the most common (Table 2).

The possibility of $A B O^{*}$ cis $A B .05$ and $A B O^{*} B A .06$ alleles being identical has been noted as the nucleotide changes reported for both alleles are the same based on dbRBC, and the $A B O *$ cisAB.05 allele has been accepted in dbRBC without publication or GenBank submission [15]. In addition, unlike the common $\mathrm{B}(\mathrm{A})$ phenotypes with $A B O * B A .04$ allele, $A B O *$ $B A .06$ phenotype tends to show strong positive reaction with monoclonal anti-A reagent, which is the same as in $A B O^{*}$ cis $A B .05$. However, in reactions with human polyclonal anti-A reagent (ShuBao, Chengdu, China), RBCs with the $A B O{ }^{*}$ cis $A B .05$ phenotype are agglutinated, while RBCs with the $A B O * B A .06$ phenotype are not agglutinated [14]. With the advent of potent monoclonal anti-A reagents, human polyclonal anti-A reagents are no longer frequently used as a routine serologic test. Unfortunately, further distinction between $A B O^{*}$ cis $A B .05$ and $A B O * B A .06$ was not feasible, due to lack of sample.

This is the first case of a Cambodian individual residing in Korea with this ABO subgroup variant. From demographic perspective, foreign residents accounted for $4.57 \%$ of total Korean population in 2018 [16]. As the number of foreign residents in Korea continues to grow annually, the need to understand rare blood groups found in other ethnicities as well as in Korean population increases.

\section{요 약}

Cis $-\mathrm{AB}$ 와 $\mathrm{B}(\mathrm{A})$ 는 $\mathrm{A}$ 와 $\mathrm{B}$ 의 당전이효소 활성을 동시에 함께 갖는 효소를 부호화하는 특징이 있 
다. cis-AB 표현형은 드물지만 한국인, 일본인 및 중국인 인구에서 일반적으로 발견된다. B(A) 혈 액형의 사례는 이전에 보고되었지만 대부분 중국 인구에 국한되어 있다. $\mathrm{ABO}$ 불일치를 가진 캄보 디아 여성의 혈구형 검사에서 항-A, 항-B시약에 강한 응집을 보였고 항- $\mathrm{A}_{1}$ 렉틴에서는 응집을 보 이지 않았다. 혈청형 검사에서 $\mathrm{A}_{1}$ 적혈구에 응집 을 보였다. $\mathrm{ABO}$ 유전자의 엑손 6 과 7 분석에서 $A B O * B .01$ 대립유전자를 동반하는 c. $803 \mathrm{C}>\mathrm{G}$ 변 이를 가진 $A B O *{ }^{*} c i s-A B .05$ 혹은 $A B O * B A .06$ 를 보 유하는 것으로 밝혀졌다. 일반 혈청학적 검사와 $\mathrm{ABO}$ 유전자 검사를 했음에도 $A B O * c i s-A B .05$ 와 $A B O * B A .06$ 를 정확히 규명할 수는 없었다. 그럼 에도 이 돌연변이들은 국내에서 처음 발견되어 보고하는 바이다.

\section{References}

1. Cho D, Kim SH, Jeon MJ, Choi KL, Kee SJ, Shin MG, et al. The serological and genetic basis of the cis-AB blood group in Korea. Vox Sang 2004;87:41-3

2. Cho D, Kim SH, Ki CS, Choi KL, Cho YG, Song JW, et al. A novel B(var) allele (547 G >A) demonstrates differential expression depending on the co-inherited ABO allele. Vox Sang 2004; 87:187-9

3. Cho D, Shin MG, Yazer MH, Kee SJ, Shin JH, Suh SP, et al. The genetic and phenotypic basis of blood group A subtypes in Koreans. Transfus Med 2005;15:329-34

4. Deng ZH, Yu Q, Liang YL, Wang DM, Su YQ, Wu GG. Characterization of a novel $\mathrm{B}(\mathrm{A})$ allele with BBBA type at the ABO blood group. J Hum Genet 2006;51:732-6

5. Lee SY, Phan MT, Shin DJ, Shin MG, Park JT, Shin JW, et al. A novel cis-AB variant allele arising from a de novo nucleotide substitution c.796A $>$ G (p.M266V) in the B glycosyltransferase gene. Transfus Med 2015;25:333-6

6. Yoon J, Youk HJ, Chang JH, Jang MA, Choi $\mathrm{JH}, \mathrm{Nam} \mathrm{MH}$, et al. Identification of the ABO* cis-AB04 allele with a unique substitution C796A: the first case in Korea. Ann Lab Med 2016;36:620-2

7. Cho D, Jeon MJ, Oh BJ, Song JW, Shin MG, Shin $\mathrm{JH}$, et al. A simplified ABO genotyping by allele-specific polymerase chain reaction. Korean J Lab Med 2005;25:123-8

8. Sano R, Nakajima T, Takahashi K, Kubo R, Kominato Y, Tsukada $\mathrm{J}$, et al. Expression of ABO blood-group genes is dependent upon an erythroid cell-specific regulatory element that is deleted in persons with the $\mathrm{B}(\mathrm{m})$ phenotype. Blood 2012;119:5301-10

9. International Society of Blood Transfusion (ISBT). Names for ABO (ISBT 001) blood group alleles. https://www.isbtweb.org/fileadmin/user upload/Working_parties/WP_on_Red_Cell_Im munogenetics_and/001_ABO_Alleles_v1.2.pdf [Online] (last visited on 19 April 2020)

10. Huang H, Jin S, Liu X, Wang Z, Lu Q, Fan $\mathrm{L}$, et al. Molecular genetic analysis of weak ABO subgroups in the Chinese population reveals ten novel $\mathrm{ABO}$ subgroup alleles. Blood Transfus 2019;17:217-22

11. Cho D, Lee JS, Park JY, Jeon MJ, Song JW, $\mathrm{Kim} \mathrm{SH}$, et al. Resolution of ABO discrepancies by ABO genotyping. Korean J Lab Med 2006; 26:107-13

12. Chun S, Choi S, Yu H, Cho D. Cis-AB, the blood group of many faces, is a conundrum to the novice eye. Ann Lab Med 2019;39:115-20

13. Zhu Z, Ye L, Li Q, Gao H, Tan Y, Cai W. Red cell immunohematology research conducted in China. Transfus Med Rev 2017;31:102-6

14. Deng ZH, Seltsam A, Ye YW, Yu Q, Li Q, 
$\mathrm{Su} Y Q$, et al. Haemolytic disease of fetus and newborn caused by $\mathrm{ABO}$ antibodies in a cisAB offspring. Transfus Apher Sci 2008;39:123-8

15. Reid MR, Lomas-Francis C, Olsson ML. The Blood Group Antigen FactsBook. 3th ed. Am- sterdam: Elsevier Academic Press, 2012

16. Korea immigration service (Korea). 2018 Korea immigration service statistics annual report. http://www.moj.go.kr/moj/2412/subview.do [Online] (last visited on 19 April 2020) 